\title{
Seroepidemiology of PPR in goats in Basrah province
}

\author{
R. K. Muhsen \\ Coll. of Vet. Med. / Unive. of Basrah \\ E mail : $\underline{\text { rkmmhf@yahoo.com }}$
}

\begin{abstract}
This study was conducted in Basrah at period from March throughout the September 2011. 1175 blood samples were collected from goats in five regions of Basrah province that have no signs of disease and no any history of vaccination to estimate the seroprevalence of PPR in goats and undergoes to the cELISA test. The results of the study revealed that the seroprevalence of the disease was $27.6 \%$. There were no significant differences in the seroprevalence in relation to sex and regions of the study $(\mathrm{P}>0.05)$. On other hand, the prevalence of PPR was higher significantly in the goats between $1-3$ years of age compared with other age groups.
\end{abstract}

\section{Introduction}

Peste des petits ruminants ( PPR ) is an acute highly contagious and economically important viral disease in small ruminants especially goats and sheep ( 1 ) with morbidity and mortality rates as high as 100\% and $90 \%$ respectively ( 2 ) . The disease characterized by high fever, oculonasal discharge, pneumonia, necrosis, and ulceration of mucous membranes and inflammation of gastrointestinal tract leading to severe diarrhea ( 3,4 and 5 ). The causative agent is enveloped , pleomorphic particles containing single

\section{Materials and methods}

A total of 1175 blood samples obtained from goats and kids of both sex with age range between one months to five years in five distinct regions of Basrah were used for serological study. Blood samples were centrifuged for ten minutes at $1500 \mathrm{rpm}$ to obtain the serum and then stored in $-20 \mathrm{C}^{\circ}$ until use. The clinical symptoms of PPR were not observed and no vaccine was used in the flocks including goats sampled for serological study . Animals housed 65 different flocks in 5 regions including east, west, north, south and centre of Basrah province .For detection of PPR virus antibodies in goats sera, a diagnostic competitive stranded RNA with negative sense as a genome and is classified under Paramyxoviridae, genus Morbillivirus ( 6 and 7 ). PPR virus is transmitted between animals such as sheep, goats and other small ruminants through the inhalation of aerosols and direct contact with ocular and nasal secretions, feces, contaminated water and feed troughs ( 8 and 9 ) The aim of this study to determined the seroprevalence of PPR in goats in Basrah province and to detect factors influencing the epidemiology of PPR virus infection .

ELISA (c ELISA) was used as a described by ( 10$)$ ). The test used monoclonal antibody to neutralizing epitope of haemoglutinin protein of the virus . The ELISA plate ( From Nunc. Maxisorp , Germany ) was coated with the PPR virus antigen and after washing proper blocking was done. After washing, test sera were added along with monoclonal antibody. Following incubation and washing, conjugate and substrate were added for color development. Absorbance was read at $492 \mathrm{~nm}$ and interpretation of the test results was made according to the paper. 

AL-Qadisiya Journal of Vet.Med.Sci.
Vol./12
No./1
2013

\section{Results}

Out of 1175 serum samples collected, 325 were positive for antibodies against PPR ( $27.6 \%$ ). The seroprevalence was higher in females 286 out of 1000 serum samples were collected ( $28.6 \%$ ) than in males 39 out of 175 ( 22.3 ) , but this differences was statistically not significant; $\mathrm{x}^{2}=$ $2.98 ; \mathrm{P}>0.05$ ( Table 1 ) . Table 2 show the seroprevalence of PPR antibodies according to the regions of the study, the seroprevalence were $26.1 \%, 26 \%, 26.8 \%, 28.3 \%$ and $31.2 \%$ for east, west, north, south and centre of Basrah province respectively. There were no significant differences in the seroprevalence among different regions $\left(\mathrm{x}^{2}=2.163 ; \mathrm{P}>0.05\right)$.Table 3 show the seroprevalence of PPR antibodies according to the age groups, The prevalence of PPR was higher in goats between $1-3$ years of age than other age groups, the seroprevalence were $39.3 \%$ in goats between $1-2$ years of age , $22.5 \%$ in the kids less than 1 year of age and $24.1 \%$ in the goats more than 3 years of age $\left(\mathrm{x}^{2}=\right.$ $29.767 ; \mathrm{P}<0.01)$.

Table 1 : Seroprevalence of PPR in goats in relation to sex

\begin{tabular}{|l|l|l|l|}
\hline & Total & Positive & $\%$ \\
\hline Males & 175 & 39 & 22.3 \\
\hline Females & 1000 & 286 & 28.6 \\
\hline Total & 1175 & 325 & 27.6 \\
\hline
\end{tabular}

$\mathrm{x}^{2}=2.98 ; \mathrm{P}>0.05$

Table 2 : Seroprevalence of PPR in goats in relation to regions of the study .

\begin{tabular}{|l|l|l|l|}
\hline & Total & Positive & $\%$ \\
\hline East & 230 & 60 & 26.1 \\
\hline West & 250 & 65 & 26 \\
\hline North & 209 & 56 & 26.8 \\
\hline South & 265 & 75 & 28.3 \\
\hline Centre & 221 & 69 & 31.3 \\
\hline
\end{tabular}

$\mathrm{x}^{2}=2.163 ; \mathrm{P}>0.05$

Table 3 : Seroprevalence of PPR in goats in relation to age groups .

\begin{tabular}{|c|c|c|c|}
\hline & Total & Positive & $\%$ \\
\hline$<1$ year & 426 & 96 & 22.5 \\
\hline $1-3$ years & 315 & 124 & 39.3 \\
\hline$>3$ years & 434 & 105 & 24.1 \\
\hline
\end{tabular}

$\mathrm{x}^{2}=29.767 ; \mathrm{P}<0.01$

\section{Discussion}

PPR has been reported in the goats and sheep in a number of countries including Afghanistan, Iran, India , Turkey, Jordan and Ethiopia ( $11,12,13$ and 14 ). Although the prevalence estimation have to be interpreted with caution it had not been possible to ensure that random selection was used at all sampling stages, the results indicate that PPR has been 


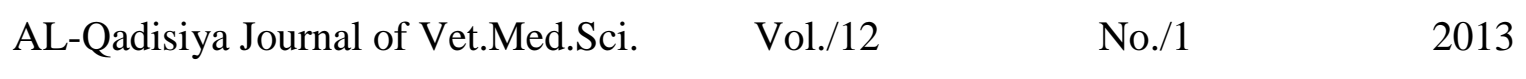

circulating in the most areas of the province before large vaccination campaigns were implemented . Lack large scale vaccination campaigns before the survey was conducted suggest that our seroprevalence estimates are likely to reflect infection ( 15 ) .This study provides valuable data on the serological status of PPR in goats in Basrah and there is no any previous study for the serological status of PPR in Iraq. Infection of PPR were reported in all regions of Basrah province indicating the heavy exposure to the virus .Serological studies carried out in Middle East and Africa show that , the prevalence of PPR infection varies between $5.8 \%-57.3 \%$ ( 16 and 17 ). The overall seroprevalence $27.6 \%$ observed in this study is higher than those reported by ( 18 and 19) in Turkey ; ( 20 ) in Uganda and ( 21 ) in Ethiopia ; but lower than those reported by ( 13 ) in Iran and ( 22 ) in Sudan. It is commonplace knowledge that the

\section{References}

1- Balamurugan, V ; Singh, R. P. ; Saravanan, P ; Sen, A ; Sakar , J ; Sahar, P ; Rasool , T. J. and Singh, R. K. ( 2002$)$. Development of indirect ELISA for detection of antibodies against PPR virus in small ruminants . Vet. Res. ( 31 ) : $335-364$.

2- Abu - Elzein , E. M. E. ; Hassanien, M. M. ; Al - Afaleq , A. I. ; Abd - Elhadi , M. A. and Housain, F. M. I. ( 1990 ) . Isolation of Peste des petits ruminants virus from goats in Saudi Arabia . The veterinary record, $127: 309-310$.

3- Lefever, P. C and Diallo , A. ( 1990 ) - Peste des petits ruminants virus . Res. Sci. Tech. off . Int. Epiz. 9 ( 4 ) : 951 - 965 . results of seroprevalence studies are influenced by many factors such as the number of sampled animals, the age of the animals, the time of sampling, the condition of care and feeding , individual differences and so on.The findings of this study also suggest that there was sex predilection of the virus and there was no significant difference in the seroprevalence of PPR in the different regions of the study suggests that the disease was prevalent throughout the area of study equally and there was no previous data for comparison. On other hand, the findings suggest that animals that were $1-3$ years old had higher seropositivity to PPR than any other age group. This result was in agreement with these reported by $(20,23,24$ and 25,$)$. It has been documented that, goats exposed to PPR at very young age may carry antibodies for $1-2$ years following exposure ( 26 ). 
7- Intizar , M. ; Ahmad , M. D. ; Anjum , A. A. ; and Hanif , A. ( 2009 ) - Comparative efficacy of PPR vaccines available in Pakistan in sheep and goats . Pak. Vet. J. 29 ( 4 ) : $202-205$.

8- Furely, W. ; Tylor, P. and Obi, T. U. ( 1989 ). An outbreak of peste des petits ruminants in a zoological collection. Vet. Res. $121: 443-447$.

9- Saliki , J. T. ; Libeau , G. ; House, J. A. ; Mebus , C. A. and Dubovi , J. ( 1993 ) . A monoclonal antibodies based blocking ELISA for specific detection and titration of PPR antibody in caprine and ovine sera. Clinc. Microbiol., 31 : 1075 - 1082 .

10- Singh , R. P. ; Sreenavasa , B. P. ; Dhar , P. and Bandyopadhyay, S. K. ( 2004 a ). A sandwich ELISA for the diagnosis of PPR infection in small ruminants using anti- neucleoprotein monoclonal antibody . Archives of virology , $149: 2155-2170$.

11- Shaila, M. S. ; Purushothaman, V. ; Bhavasar, D. ; Venogopal , K. and Venkatesan , R. A. ( 1989 ) - Peste des petits ruminants in sheep in India . Vet. Rec. , 125 : 602 .

12- Mojak , A. A. ( 2001 ) . Animal health components . AFG / 100 / 105 Manual report. Islamabad . Pakistan .

13- Abdollapour , G. ; Roofi , A. ; Najafi ， J. ; Sasani , F. and Sakhaie , E. ( 2006 ) . Clinical and paraclinical findings of a recent outbreak of PPR in Iran . J. Vet. Med. B, $25: 14-16$.

14- Zahur, A. B. ; Ullah, A. ; Irshad, H. ; Farooq , M. S. ; Hussain , M. and Jahangir , M. ( 2009 ). Epidemiological investigation of peste des petits ruminants outbreak in Afgan sheep in Pakistan . Pakistan Vet. J. ( 4 ) : $174-178$.

15- Abraham , G. ; Sintayehu , A. ; Libeau , G. ; Albina , E. ; Roger , F. ; Laekemariam , Y. ; Abayneh , D. and Awok , K. M. ( 2005 ) . Antibody seroprevalence against peste des petits ruminants virus in camels, cattle, goats and sheep in Ethiopia . Prev. Vet. Med. , $70 \quad(1-2): 51-57$.

16- Lefever , P. J. ; Daillo , A. ; Schenkel , F. ; Hussein , S. and Staak , G. ( 1990 ). Serological evidence of Peste des petits ruminants in Jordan. Vet. Rec. $, 128,110$.

17- Tylor , W. P. ( 1979 ). Serological studies with the virus of Peste des petits ruminants in Nigeria. Res. Vet. Sci., $26: 236-242$.

18- Tatar, N. ; Erturk, A. ; Kabakli , O. ; Akkoco , N. ; Incoglu , S. ; Ulker, U. and Dakman , A. ( 2002 ). Seroprevalence of PPR in Turkey . Vet. Microbiol. Etlik. Vet. Microbiol. , Dery , $13: 15-31$.

19- Albayrak , H. and Alkan , F. ( 2009 ). PPR virus infection in sheep in Black sea region of Turkey : Epidemiology and diagnosis by RT . PCR and virus isolation . Vet. Res. Comm. ( 33 ) : 241 249.

20- Luka , P. D. ; Erume , J. ; Mwine , F. N. and Ayebazibwe, C. (2011). Seroprevalence of Peste des petits ruminants antibodies in sheep and goats after vaccination in Karamija , Uganda : Implication on control . Internat. J. Ani. Vet. Advances , $3(1): 18-22$.

21- Waret - Szkuta , A. ; Roger , F. ; Chaveranc , D. ; Yigesu , L. ; 
$\begin{array}{llll}\text { AL-Qadisiya Journal of Vet.Med.Sci. } & \text { Vol./12 } & \text { No./1 }\end{array}$

Libeau , G. ; Pfeiffer , D. and

Guitian , J. ( 2008 ). Peste des petits ruminants in Ethiopia of a national serological survey . Vet. Rec. ( 4 ) : 34 .

22- Osman , N. A. ; Ali , A. S. ; Mahasin , E, A. and Fadol, R. M. A. ( 2009 ). Antibody seroprevalence against PPR virus in sheep and goats in Sudan . Trop. Anim. Health. Prod. , 41 : 1449 - 1435 .

23- Abubakar , M. Jamal , S. M. ; Arshad , J. M. ; Hussain , M. and Ali , Q. (2009) Peste des petits ruminants virus (PPRV) infection, its association with species, seasonal variation and geography. Trop. Anim. Health. Prod., $41: 1197$ - 1202.

24- Ozkul, A.; Akca , Y.; Alkan, F.; Barret, T.; Karaoglu, T.; Dagalp , S. B. ; Anderson , J. ; Yesilbag
, K. ; Cokcaliskan , C. ; Gencay , A and Burgue, I. ( 2002). Prevalence , distribution and host range of Peste des petits ruminants (PPR) virus . Turkey . Emerg . Infect. Dis, $8: 708-$ 712 .

25- Singh , R. P. ; Sreenavasa , B. P. ; Dhar, P. and Bandyopadhyay, S. K. $(2004$ b) . Prevalence , distribution and host range of Peste des petits ruminants virus infection in small ruminants in India . Rev. Sci. Tech. , 23 : $807-819$.

26- Dhar , P. ; Sreenivasa , B. P. , Barret , T. Corteyn , M. ; Singh , R. P. and Bandyyopadhyay, , S. K. (2002) . recent epidemiology of Peste des petits ruminants virus by polymerase chain reaction assay . J. Virol. Methods. 100 : $17-25$.

\section{الخلاصة}

أجريت هذه الدراسة في البصرة للفترة من اذار الى أيلول 2011 ـ تم جمع الإمة 1175 نموذج دم من الماعز غير الملقح

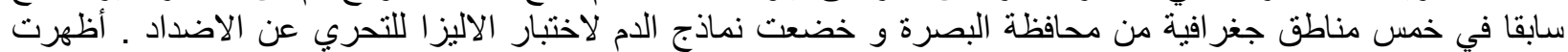

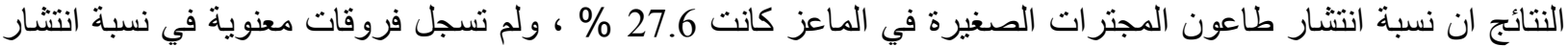

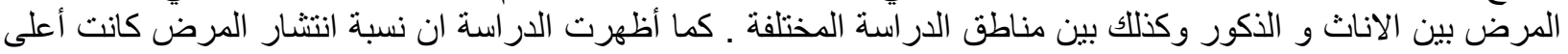

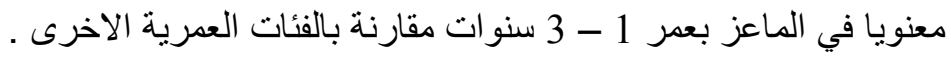

